\title{
Diagnostic Value of Elastosonographic Evaluation of Cervix in Idiopathic Recurrent Spontaneous Miscarriage in the First Trimester
}

\author{
ilk Trimester Tekrarlayan Spontan Gebelik Kayıplarında Servikal \\ Elastosonografinin Tanısal Değeri
}

\author{
Doğa Fatma Öcal, Yasemin Çekmez, Esengül Türkyılmaz*, İsmail Burak Gültekin, Yeşim Uçar, \\ Mehmet Firat Mutlu**, Tuncay Küçüközkan \\ Dr. Sami Ulus Maternity, Child Health and Diseases Training and Research Hospital, Clinic of Obstetrics and Gynecology, Ankara, Turkey \\ ${ }^{*}$ Atatürk Training and Research Hospital, Clinic of Obstetrics and Gynecology, Ankara, Turkey \\ **Yüksek Ihtisas Üniversitesi Koru Hospital, Clinic of Obstetrics and Gynecology, Ankara, Turkey
}

\section{Abstract}

Aim: To detect prognostic role of cervical elastosonography (ES) among women with a history of idiopathic recurrent spontaneous miscarriage (IRSM) in early pregnancy.

Methods: There were 40 women enrolled in the study. Of the 40, 20 were women diagnosed with IRSM in the first trimester and 20 were healthy women who had at least one childbirth experience. All patients underwent ES evaluation of the cervix. Strain ratio values of certain cervical tissue were recorded for all women.

Results: The results of elastosonographic measures showed that external part of the upper lip of the cervix was significantly softer than the internal part and lower lip in women with IRSM. However, for women who had not experienced miscarriage, the results were not different. There were no significant differences observed between cervical length and elasticity among either group.

Conclusion: Although we found that Region A was softer than Region $C$ and $D$ in women with IRSM, we also found similar results for women who have not experienced miscarriage. Our results support that cervical elasticity may not play a central role in the detection of etiopathogenesis of IRSM. Further studies with larger groups are needed.

Keywords: Elastosonography, recurrent spontaneous miscarriage, cervix, elastography
Öz

Amaç: illk trimesterde tekrarlayan idiyopatik spontan düşükleri olan kadınlarda servikal elastosonografinin klinik ve tanısal önemini belirlemek.

Yöntemler: Toplam 40 hasta çalışmaya alındı. Bunlardan 20 tanesi ilk trimesterde tekrarlayan idiyopatik spontan düşükleri olan kadınlar ve 20 tanesi de bir kez doğum yapmış sağlıklı kadınlardı. Tüm hastalara servikal elastografi uygulandı. Her hasta için doku gerginlik oranları elde edildi.

Bulgular: Elastosonografik ölçüm sonuçlarına göre idiyopatik tekrarlayan gebelik kaybı olan kadınlarda serviksin üst ve dış kısmının iç ve alt kısımlarından daha yumuşak olduğu saptandı. Ancak düşük yapmamış kadınlarda da sonuçlar farklı değildi. Gruplar arasında servikal uzunluk ve elastisite açısından istatistiksel anlamlı fark saptanmadı.

Sonuç: Her ne kadar idiyopatik tekrarlayan gebelik kaybı olan kadınlarda A bölgesini $C$ ve $D$ bölgelerinden daha yumuşak bulmuşsak da düşük yapmamış kadınlarda da benzer sonuçlar bulduk. Bizim sonuçlarımız idiyopatik tekrarlayan spontan düşüklerin etyopatogenezinin belirlenmesinde servikal elastisitenin rolü olmadığını göstermektedir. Geniş hasta sayısına sahip ileri çalışmalara ihtiyaç vardır.

Anahtar Sözcükler: Elastosonografi, idiyopatik tekrarlayan düşükler, serviks, elastografi
Address for Correspondence/Yazıșma Adresi Doğa Fatma Öcal

Dr. Sami Ulus Maternity, Child Health and Diseases Training and Research Hospital, Clinic of Obstetrics and Gynecology, Ankara, Turkey Phone: +90 5336599889 E-mail: eadoga@yahoo.com Received/Geliş Tarihi: 28 March 2016 Accepted/Kabul Tarihi: 16 May 2016
- Copyright 2016 by The Medical Bulletin of Haseki Training and Research Hospital The Medical Bulletin of Haseki published by Galenos Yayınevi. ๑Telif Hakkı 2016 Haseki Eğitim ve Araştırma Hastanesi Haseki Tıp Bülteni, Galenos Yayınevi tarafından basıımıştır. 


\section{Introduction}

Three or more repetitive pregnancy losses before 20 weeks are defined as recurrent spontaneous miscarriage (RSM) $(1,2)$. RSM affects approximately $1-3 \%$ of women. There may be several factors associated with recurrent pregnancy losses. Despite many known risk factors, the etiology is still obscure in almost half of the women with RSM (3).

Cervical abnormalities are well-known risk factors for prematurity (4). Cervical insufficiency, cervical dilatation, and the angle between cervix and corpus uteri are all believed to be associated risks of RSM (5). These risk factors may be diagnosed by the use of ultrasound.

Elastosonography (ES) is a relatively new technique in obstetrics and gynecology practice. It compares the tissues according to the levels of deformation. There are reports about the use of ES for differential diagnosis of masses in breast and thyroid imaging. Also, applications in gynecology and obstetrics have been reported (6-10).

In the present study, cervix uteri was examined by ES to detect the prognostic value of ES in women with idiopathic RSM (IRSM) and the utility of ES to predict IRSM.

\section{Methods}

The study was performed in Dr. Sami Ulus Maternity, Child Health and Diseases Training and Research Hospital, Clinic of Obstetrics and Gynecology between January 2014 and April 2014. Ethical approval was received from Keçiören Medical and Research Hospital's review board. Written informed consent was obtained from each woman. 20 women, who had been diagnosed with IRSM with no delivery history, constituted the study group. 20 women who had one caesarean section with no history of vaginal delivery, preterm delivery or abortion were included in the control group. None of the women had any history of surgical procedures, such as cervical conization, which may affect the cervix. We defined IRSM for this study as three or more spontaneous miscarriages, which have not been shown to correlate with currently known causes of RSM.

All the sonographic examinations were performed with Hitachi real-time elastography (RTE), HI-VISION Preirus, Japan ultrasound device. We used the transvaginal probe of the device. The same operator, who had 10 years of experience in ultrasound examinations, and blinded to the study design acquired the ES images. The women positioned in the dorsal lithotomy position with an empty bladder. Elastosonographic evaluation was performed by a transvaginal probe with 4-13 $\mathrm{MHz}$ bandwidth. After placing the vaginal probe in the anterior fornix and imaging the endocervical area clearly, the extent of the cervix was measured in a sagittal view. We applied repetitive compressions, each taking almost one second, over the cervix to perform RT ES and acquire compression decompression cycles. The two images B-mode and elastogram were demonstrated side-by-side on the screen. The most symmetrical waveform was selected among the cycles. Color mapped elastosonographic images were obtained. There were different colors each showing the different degree of tissue elasticity. Tissues with low elasticity were represented by red signal while the ones with high elasticity were green.

Four parts of the cervix were selected: the external and superior lip (region A), the internal and superior lip (region B), the internal and inferior lip (region C), and the external and inferior lip (region D), as shown in Figure 1 and 2. Our reference point for each region was the adjacent myometrial
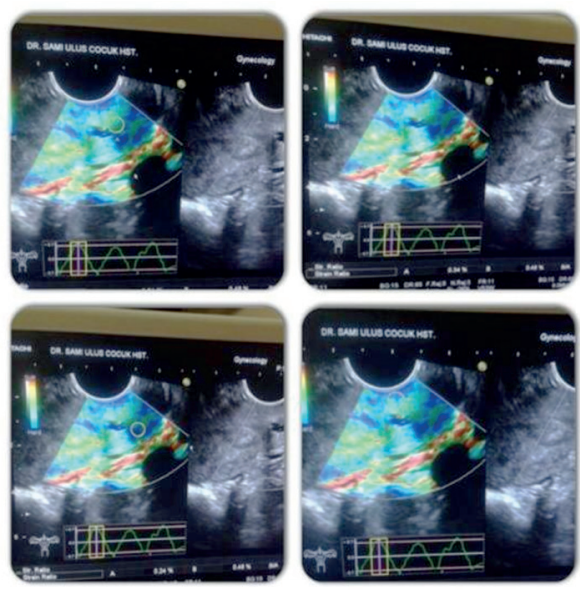

Figure 1. Cervical elastographic image showing regions of interest selected for quantification in cases without idiopathic recurrent spontaneous miscarriage. Clockwise from the top left; Region A: external and superior cervical lip. Region B: internal and superior cervical lip. Region C: internal and inferior cervical lip. Region D: external and inferior cervical lip
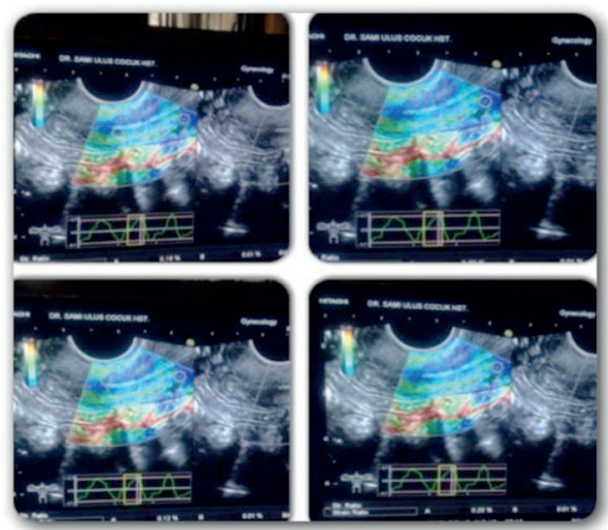

Figure 2. Cervical elastographic image showing regions of interest selected for quantification in cases withidiopathic recurrent spontaneous miscarriage. Clockwise from the top left; Region A: external and superior cervical lip. Region B: internal and superior cervical lip. Region C: internal and inferior cervical lip. Region D: external and inferior cervical lip 
tissue. One 3-5 mm-diameter circle was placed on each tissue to calculate the strain ratio (one was on the interested area of the cervix and the other was on the reference myometrial tissue). The strain ratios of the interested areas were calculated automatically by the software.

We performed the statistical analyses by the Statistic Package for Social Sciences (SPSS) version 16.0. For comparing the groups, independent samples t-test and chi-square test were used. The elastosonographic values of different areas of the cervix were compared by repeated measures ANOVA test. A $p$ value of less than 0.05 was considered statistically significant. $\alpha=0.0125$ value was used for binary comparison of different regions and $p<\alpha$ was considered statistically significant.

\begin{tabular}{|l|l|l|l|}
\hline \multicolumn{4}{|l|}{ Table 1. Group characteristics } \\
\hline & $\begin{array}{l}\text { Study } \\
\text { group } \\
\text { (with } \\
\text { IRSM) }\end{array}$ & $\begin{array}{l}\text { Control group } \\
\text { (without } \\
\text { IRSM) }\end{array}$ & $p$ \\
\hline Age & $24.4 \pm 2.4$ & $23 \pm 1.9$ & $p>0.05$ \\
\hline Gravidity & $4(3-11)$ & $1(1-1)$ & $p<0.05$ \\
\hline Parity & $0(0-0)$ & $1(1-1)$ & $p<0.05$ \\
\hline Abortion & $4(3-11)$ & $0(0-0)$ & $p<0.05$ \\
\hline Curettage after abortion & $0(0-2)$ & $0(0-0)$ & $p>0.05$ \\
\hline IRSM: Idiopathic recurrent spontaneous miscarriage \\
\hline
\end{tabular}

\begin{tabular}{|c|c|c|c|}
\hline & $\begin{array}{l}\text { Study group } \\
\text { (with IRSM) }\end{array}$ & $\begin{array}{l}\text { Control } \\
\text { group } \\
\text { (without } \\
\text { IRSM) }\end{array}$ & $p$ \\
\hline srA & $1.23 \pm 0.97$ & $1.28 \pm 1.77$ & $p>0.05$ \\
\hline $\mathrm{srB}$ & $1.13 \pm 1.16$ & $0.98 \pm 0.92$ & $p>0.05$ \\
\hline $\mathrm{srC}$ & $0.93 \pm 1.22$ & $0.76 \pm 0.72$ & $p>0.05$ \\
\hline srD & $1.23 \pm 0.97$ & $0.85 \pm 1.12$ & $p>0.05$ \\
\hline Cervical length $(\mathrm{cm})$ & $36.67 \pm 4.1$ & $36.37 \pm 4.74$ & $p>0.05$ \\
\hline
\end{tabular}

\begin{tabular}{|l|l|l|l|l|l|}
\hline \multicolumn{6}{|c|}{$\begin{array}{l}\text { Table 3. Comparison of elastographic measurements for } \\
\text { different regions of the cervix between two groups }(\alpha=0.0125)\end{array}$} \\
\hline $\begin{array}{l}\text { Cervical } \\
\text { regions }\end{array}$ & $\begin{array}{l}\text { Mean } \\
\text { difference }\end{array}$ & $\begin{array}{l}\text { Standard } \\
\text { error }\end{array}$ & $\begin{array}{l}95 \% \mathrm{Cl} \\
\text { Lower } \\
\text { bound }\end{array}$ & $\begin{array}{l}95 \% \mathrm{Cl} \\
\text { Upper } \\
\text { bound }\end{array}$ & $\begin{array}{l}\text { Signifi- } \\
\text { cance }\end{array}$ \\
\hline srA - srB & 0.14012 & 0.06038 & 0.01995 & 0.26030 & 0.023 \\
\hline srA - srC & 0.34813 & 0.06528 & 0.21819 & 0.47806 & 0.000 \\
\hline srA - srD & 0.29263 & 0.08572 & 0.12200 & 0.46325 & 0.001 \\
\hline srB - srC & 0.20800 & 0.06388 & 0.08085 & 0.33515 & 0.002 \\
\hline srB - srD & 0.15250 & 0.68021 & 0.00113 & 0.30387 & 0.048 \\
\hline srC - srD & -0.05550 & 0.06674 & -0.18833 & 0.07733 & 0.408 \\
\hline Cl: Confidence interval, sr: Strain ratio & & \\
\hline
\end{tabular}

\section{Results}

Table 1 shows the characteristic properties of the subjects. Both the study group and control group were similar for maternal age (years) at admission $(p>0.05)$. Cervical lengths were observed to be similar between the groups ( $p>0.05)$ (Table 2).

According to the elastographic measurements, the superior and external part of the cervix (region A) was the softest area in both groups $(p<0.05)$ (Table 2, Figures 1 , 2). There were no significant differences in elastographic values of different parts of the cervix between the groups (Table 3). When elastographic values in different parts of the cervix in each class itself were examined, it was observed that presented region $A$ as being softer than region $D$ in all groups -women with IRSM and without miscarriage$(p<0.0125)$ (Tables 4 and 5, Figure 3, 4).

\section{Discussion}

Repetitive losses of pregnancies (three or more) in early weeks of gestation is called as recurrent pregnancy miscarriage $(1,2)$. Although approximately half of the cases were unexplained general etiologies of IRPM consisted of anatomic abnormalities, immunological

\begin{tabular}{|c|c|c|c|c|c|}
\hline $\begin{array}{l}\text { Cervical } \\
\text { regions }\end{array}$ & $\begin{array}{l}\text { Mean } \\
\text { differ- } \\
\text { ence }\end{array}$ & $\begin{array}{l}\text { Standard } \\
\text { error }\end{array}$ & $\begin{array}{l}95 \% \mathrm{Cl} \\
\text { Lower } \\
\text { bound }\end{array}$ & $\begin{array}{l}95 \% \mathrm{Cl} \\
\text { Upper } \\
\text { bound }\end{array}$ & $\begin{array}{l}\text { Signifi- } \\
\text { cance }\end{array}$ \\
\hline srA- srB & 0.10450 & 1.00108 & -0.21566 & 0.42466 & 0.513 \\
\hline srA - srC & 0.29950 & 1.21384 & -0.08870 & 0.68770 & 0.127 \\
\hline srA - srD & 0.34300 & 0.89959 & 0.05530 & 0.63070 & 0.012 \\
\hline$s r B-s r C$ & 0.19500 & 0.62645 & -0.00535 & 0.39535 & 0.056 \\
\hline $\mathrm{srB}-\mathrm{srD}$ & 0.23850 & 1.11929 & -0.11947 & 0.59647 & 0.186 \\
\hline $\mathrm{srC}-\mathrm{srD}$ & 0.04350 & 1.11145 & -0.31196 & 0.39896 & 0.806 \\
\hline
\end{tabular}

Table 5. Intraclass correlation of elastographic measurements for different regions of the cervix in women without idiopathic recurrent pregnancy miscarriage $(\alpha=0.0125)$

\begin{tabular}{|l|l|l|l|l|l|}
\hline $\begin{array}{l}\text { Cervical } \\
\text { regions }\end{array}$ & $\begin{array}{l}\text { Mean } \\
\text { difference }\end{array}$ & $\begin{array}{l}\text { Standard } \\
\text { error }\end{array}$ & $\begin{array}{l}95 \% \text { Cl } \\
\text { Lower } \\
\text { bound }\end{array}$ & $\begin{array}{l}\text { 95\% Cl } \\
\text { Upper } \\
\text { bound }\end{array}$ & $\begin{array}{l}\text { Signifi- } \\
\text { cance }\end{array}$ \\
\hline srA - srB & 0.29750 & 1.51129 & -0.18584 & 0.78084 & 0.221 \\
\hline srA - srC & 0.52175 & 1.37665 & 0.08148 & 0.96202 & 0.021 \\
\hline srA - srD & 0.39800 & 1.45750 & -0.06813 & 0.86413 & 0.009 \\
\hline srB - srC & 0.22425 & 0.67978 & 0.00685 & 0.44165 & 0.044 \\
\hline srB - srD & 0.10050 & 0.82557 & -0.16353 & 0.36453 & 0.446 \\
\hline srC - srD & -0.12375 & 0.77112 & -0.37036 & 0.12286 & 0.316 \\
\hline Cl: Confidence interval, sr: Strain ratio \\
\hline \multicolumn{7}{|l}{} \\
\hline
\end{tabular}




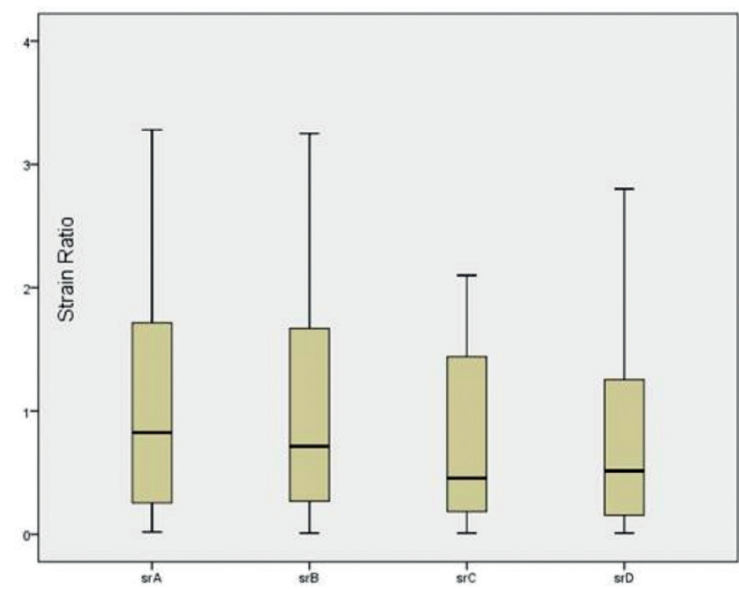

Figure 3. Box-and-whisker plots of elastographic measurements for different regions of the cervix in women with idiopathic recurrent pregnancy miscarriage. srA: the external and superior cervical lip. srB: the internal and superior cervical lip. srC: the internal and inferior cervical lip. srD: the external and inferior cervical lip. The medians (lines within boxes), interquartile ranges (IQR, boxes), and values within 1.5 IQR (whiskers) are also shown. sr: Strain ratio

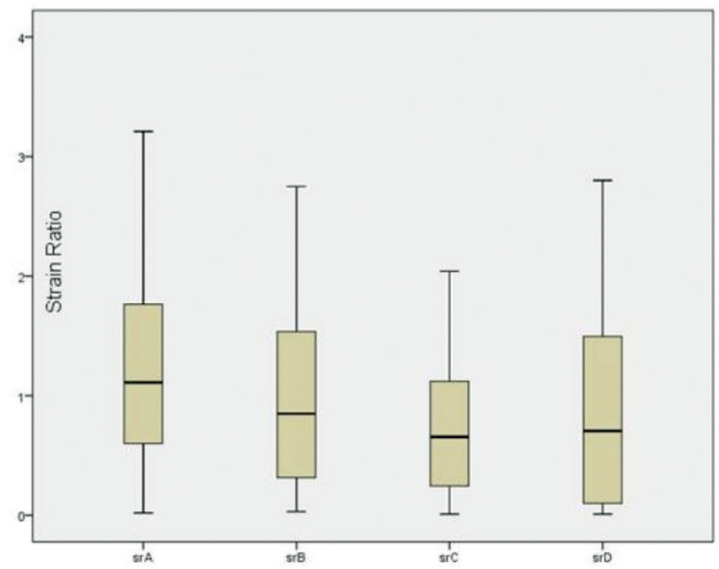

Figure 4. Box-and-whisker plots of elastographic measurements for different regions of the cervix in women without idiopathic recurrent pregnancy miscarriage. srA: the external and superior cervical lip. srB: the internal and superior cervical lip. srC: the internal and inferior cervical lip. srD: the external and inferior cervical lip. The medians (lines within boxes), interquartile ranges (IQR, boxes), and values within 1.5 IQR (whiskers) are also shown. sr: Strain ratio

factors, chromosomal abnormalities, various infections, endocrinopathies, and environmental factors. Generally the etiology is unknown, which we define as "idiopathic" (11).

We can perform several tests to evaluate a woman who has a history of RPM. Ultrasonographic measurement of the length of the cervix is usually performed for detecting the abnormalities of the uterus and cervix (11). In our study, we compared the women according to the cervical length measurements. The results were similar between the groups. According to our results, we conclude that to measure the length of the cervix by ultrasound is not a helpful method to evaluate women with IRPM.

In recent years ultrasound-derived ES has become popular in obstetrics and gynecology. There have been several studies about ES; some of them included cervical ES. These studies focused on the prediction of preterm birth through the use of ES to evaluate the cervix. Hernandez-Andrade et al. (12) for instance, used ES for evaluating the strain of cervical tissue and examined the association between low strain levels of internal cervical ostium and lower risk of spontaneous preterm delivery.

In our previous study, we evaluated the cervix in women who experienced pregnancy loss related to cervical insufficiency (10).

In the present study, we investigated the cervix uteri through the use of ES in women with IRPM presenting in their first trimester. According to the elastographic measurements, we found that the external part of the upper lip of the cervix was significantly softer than the internal part and lower lip in each group. This result was compatible with the results of Molina et al. (13) who found that the superior and external regions of the cervix were significantly softer than the inferior and internal regions. However, we believe that this result may still be open to criticism. We assume that different studies on cervical thickness to be performed in the future may report different results.

Based on the elastographic measurement data, we found that the superior and external part of the cervix (region A) was the softest area in both groups $(p<0.05)$ (Table 2). When we examined intraclass correlation of elastographic measurements in different regions of the cervix, we observed that region A was softer than region $D$ in both study and control groups (Tables 4, 5). According to our results, we could not find a statistically significant difference between the two groups.

As far as we could discern, this is the first study evaluating the cervix with ES in patients with a history of IRPM. The small sample size proved to be the major obstacle for this study. The force applied during the ES for compressing the tissue cannot be standardized, and this is the major limitation of the ES technique.

\section{Conclusion}

In conclusion, we report that ES is not a reliable method to evaluate these patients. Therefore, further studies are required in order to report more comprehensive results.

\section{Ethics}

Ethics Committee Approval: The study were approved by the Local Ethics Committee of Keçiören Medical and Research Hospital, Informed Consent: Consent form was filled out by all participants.

Peer-review: Externally and Internally peer-reviewed. 


\section{Authorship Contributions}

Concept: Doğa Fatma Öcal. Design: İsmail Burak Gültekin. Data Collection or Processing: Yeşim Uçar. Analysis or Interpretation: Esengül Türkyllmaz. Literature Search: Mehmet Firat Mutlu. Writing: Yasemin Çekmez.

Conflict of Interest: No conflict of interest was declared by the authors.

Financial Disclosure: The authors declared that this study received no financial support.

\section{References}

1. Toth $B$, Jeschke $U$, Rogenhofer $N$, et al. Recurrent miscarriage: current concepts in diagnosis and treatment. J Reprod Immunol 2010;85:25-32.

2. Ford HB, Schust DJ. Recurrent pregnancy loss: etiology, diagnosis, and therapy. Rev Obstet Gynecol 2009;2:76-83.

3. Bates SM. Consultative hematology: the pregnant patient pregnancy loss. Hematology Am Soc Hematol Educ Program 2010;2010:166-72.

4. Mazza E, Parra-Saavedra M, Bajka M, et al. In vivo assessment of the biomechanical properties of the uterine cervix in pregnancy. Prenat Diagn 2014;34:33-41.

5. Kirchoff $\mathrm{H}$, Haupt W. [Value of radiographic studies on the cervix uteri and internal uterine orifice with reference to irregular pregnancies (abortus-premature labor)]. Zentralbl Gynakol 1977;99:1159-65.
6. Cespedes I, Ophir J, Ponnekanti H, et al. Elastography: elasticity imaging using ultrasound with application to muscle and breast in vivo. Ultrason Imaging 1993;15:73-88.

7. Ophir J, Alam SK, Garra B, et al. Elastography: ultrasonic estimation and imaging of the elastic properties of tissues. Proc Inst Mech Eng H 1999;213:203-33.

8. Ophir J, Cespedes I, Ponnekanti H, et al. Elastography: a quantitative method for imaging the elasticity of biological tissues. Ultrason Imaging 1991;13:111-34.

9. Parker KJ, Doyley MM, Rubens DJ. Imaging the elastic properties of tissue: the 20 year perspective. Phys Med Biol 2011;56:R1-R29.

10. Ocal FD, Cekmez Y, Erdogdu E, et al. The utility of cervical elastosonography in prediction of cervical insufficiency: cervical elastosonography and cervical insufficiency. J Matern Fetal Neonatal Med 2015;28:812-8.

11. Feltovich $H$, Hall TJ, Berghella V. Beyond cervical length: emerging technologies for assessing the pregnant cervix. Am J Obstet Gynecol 2012;207:345-54.

12. Hernandez-Andrade E, Romero R, Korzeniewski SJ, et al. Cervical strain determined by ultrasound elastography and its association with spontaneous preterm delivery. J Perinat Med 2014;42:159-69.

13. Molina FS, Gomez LF, Florido J, et al. Quantification of cervical elastography: a reproducibility study. Ultrasound Obstet Gynecol 2012;39:685-9. 